\section{Small is beautiful}

Sometimes size really does matter, in issues relating to English as in other things. Sheer vastness and numbers inevitably draw our attention, especially at the present time, to linguistic and many other matters in China, and in this issue (as in others in recent times) we continue to pay close attention to both the vastness and the numbers. Certainly, in ET - as elsewhere in print and on screen - matters relating to such a rising world player are of key concern, and notably in ET76, we continue the debate on issues that are fundamental to the world's way of acknowledging linguistic dynamism, statistics, and (in effect) clout.

The English language complex is vast and potently distributed throughout the planet, but the Chinese language complex is larger still, though it is concentrated in one region, yet through its rapidly increasing economic and cultural significance its nature and prospects demand thorough-going international reassessment. While that historic reassessment proceeds, English will continue to be the language most sought after among the Chinese themselves, and millions of them will in due course be competent in the world's two most extensive means of communication. This has not yet happened, as our contributors indicate in this issue, but when it does happen it will be a unique development in human history.

Yet there is another sense of size, as in 'Small is beautiful'. Here one thinks of nations whose core languages are not prominent on the world's stage, yet sustain and are sustained by cultures with passionately enduring stories, and such languages have to find a means of co-existing securely alongside such juggernauts as English and Chinese.

In this issue (heading our usual spread of topics) are reports on two such countries, Finland and Macedonia, the first in northeastern and the second in south-eastern Europe. In these accounts we see how national languages of limited global reach (yet with their own diasporas) are sustained in the homeland, often despite complex and difficult historical situations. We also see how they co-occur in their respective educational systems with several other languages, among which English is inevitably significant - and not simply 'to be applied externally'.

Tom McArthur

The editorial policy of English Today is to provide a focus or forum for all sorts of news and opinion from around the world. The points of view of individual writers are as a consequence their own, and do not reflect the opinion of the editorial board. In addition, wherever feasible, ET generally leaves unchanged the orthography (normally British or American) and the usage of individual contributors, although the editorial style of the journal itself is that of Cambridge University Press. (c) Cambridge University Press 2003.

No contents may be reproduced by any means without the permission of Cambridge University Press.

English Today (ISSN 0266-0784) is a quarterly.

Publisher: Cambridge University Press, The Edinburgh Building, Cambridge CB2 2RU, United Kingdom. Telephone (01223) 312393 Email:

(01223) 312393 Email:
journals_marketing@cup.cam.ac.uk Subscriptions: The 2003 subscription price (excluding VAT) for four issues for libraries and institutions, which includes print and electronic access, is f79.00 outside of North America; $\mathrm{f} 32.00$ for individuals; $f 24$ for students and the retired. The electronic-only price available to institutional

subscribers is $f 71.00$. Prices include delivery by air where appropriate. Apply to Jane Crossland at the above address.

Advertising Sales: write to the

Advertising Promoter at the above address.

USA, CANADA AND MEXICO: Publisher: Cambridge University Press, 40 West 20th Street, New York, NY 10011-4211, USA

Telephone (212) 9243900.

Subscriptions: The 2003 subscription

price (excluding VAT) for four issues for libraries and institutions, which includes print and electronic access, is $\$ 124.00$ in USA, Canada and Mexico; $\$ 50.00$ for individuals; $\$ 37$ for students and the retired. The electronic-only price available to institutional subscribers is $\$ 108.00$. Apply to Marianne Headrick at the above address.

Advertising Sales: write to the Advertising Coordinator at the above address.

Periodicals postage paid at New York, NY and at additional mailing offices. POSTMASTER: send address changes in USA, Canada and Mexico to English Today, Cambridge University Press, 110 Midland Avenue, Port Chester, New York, NY 10573-4930, USA.

Japanese prices for institutions are available from Kinokuniya Company Ltd, P.O. Box 55, Chitose, Tokyo 156, Japan.

Contacting the Editor: Email Dr Tom McArthur at <Scotsway@aol.com> or write to him at 22-23 Ventress Farm Court, Cherry Hinton Road, Cambridge CB1 8HD, UK. Tel 01223245934.

Internet access This journal is included in the Cambridge Journals Online service which can be found at http://uk.cambridge.org/journals. For further information on other Press titles access http://uk.cambridge.org. Designed and typeset by Peter Ducker. Printed in the United Kingdom at the University Press, Cambridge. 